\title{
Title: The prognostic significance of survivin expression in patientswith HNSCC: a systematic review and meta-analysis
}

\author{
Liu-qing Zhou \\ Huazhong University of Science and Technology \\ Yao Hu \\ Huazhong University of Science and Technology \\ Hong-jun Xiao ( $\nabla$ xhjent_whxh@hust.edu.cn ) \\ Huazhong University of Science and Technology
}

\section{Research Article}

Keywords: survivin, head and neck squamous cell carcinoma, prognosis, meta-analysis

Posted Date: January 6th, 2021

DOI: https://doi.org/10.21203/rs.3.rs-122485/v1

License: (c) (i) This work is licensed under a Creative Commons Attribution 4.0 International License. Read Full License

Version of Record: A version of this preprint was published at BMC Cancer on April 17th, 2021. See the published version at https://doi.org/10.1186/s12885021-08170-3. 


\section{Abstract}

Background: Survivin has been recently identified as a promising novel therapeutic target and prognostic marker in different types of cancer. Here we conducted a comprehensive meta-analysis to better clarify they the precise prognostic and diagnostic value of survivin in head and neck squamous cell carcinoma (HNSCC).

Methods: Database of PubMed (Medline), Embase, and Web of Science were systematically searched for related published literature up to September 2020. Pooled hazards ratios (HRs) and related $95 \%$ confidence intervals (Cls) were used to estimate the association of survivin expression and survival outcomes in HNSCC patients.

Results: Twenty eight studies with 4891 patients were finally included in this meta-analysis, the pooled analysis indicated that the survivin expression was significantly correlated with poorer overall survival (OS) (HR, 2.02; 95\% Cl, 1.65-2.47, $\mathrm{P}<0.001$ ), and poorer disease-free survival (DFS)/ disease-specific survival (DSS) $(H R=2.03,95 \% \mathrm{Cl}: 1.64-2.52, \mathrm{P}<0.001 ; \mathrm{HR}=1.92,95 \% \mathrm{Cl}: 1.41-2.60, \mathrm{P}<0.001$, receptively). In addition, we observed the similar results in subgroup analysis stratified by different cancer types, such as laryngeal squamous cell carcinoma (LSCC) $(\mathrm{HR}=1.35,95 \% \mathrm{Cl}$ : 1.05-1.74, $\mathrm{P}<0.001)$, oral squamous cell carcinomas (OSCC) $(\mathrm{HR}=2.45,95 \% \mathrm{Cl}: 1.89-3.17, \mathrm{P}<0.001)$, nasopharyngeal carcinoma $(\mathrm{NPC})(\mathrm{HR}=2.53,95 \% \mathrm{Cl}: 1.76-3.62, \mathrm{P}<0.001)$ and HNSCC (HR $=1.52,95 \% \mathrm{Cl}: 1.25-1.86, \mathrm{P}<0.001)$.

Conclusions: Our results suggested that survivin is predictors of worse prognosis in HNSCC patients. Hence, survivin is a potential therapeutic target for HNSCC.

\section{Introduction}

Head and neck squamous cell carcinoma (HNSCC) is ranking as the sixth most prevalent cancer worldwide [1], they develop from the squamous mucosa of the upper aerodigestive tract, including nasal cavity, nasopharynx, larynx, hypopharynx, oropharynx and so on. Squamous cell carcinoma (SCC) accounts for up to $90 \%$ of malignant tumor in the head and neck region. The group of malignancies have similar pathogenesis, staging system, therapeutic strategy, and prognosis despite they arise from different sites of head and neck region, hence, it is rational to classify them into one category, HNSCC [2]. There are several risk factors associated with HNSCC, such as environmental exposures, tobacco use, alcohol consumption and so on [3]. Although the diagnosis and multimodality treatments improved quickly, the 5-year survival rate still remains very low due to the complex anatomy of head and neck region [4]. Therefore, it is necessary to identify more reliable new prognostic biomarkers and therapeutic targets.

Survivin, an important member of the 'inhibitor of apoptosis' (IAP) family, is encoded by baculoviral inverted repeats (BIR) C5 gene [5]. The expression is minimal in normal tissues, however, strong survivin expression is largely observed in numerus cancers [6]. Survivin is an anti-apoptotic factor and regulate intrinsic and extrinsic apoptotic pathways by interacting with many factors. Survivin also play key roles in cellular stress response by interfering with autophagy. Different proteins of the autophagic machinery, such as Beclin 1, chemokine ligand 2 and light chain 3 interact with survivin [7, 8]. In addition, survivin expression is associate with the process of angiogenesis, it overcomes $\mathrm{G} 2 / \mathrm{M}$ phase of the cell cycle and causes mitotic progression in most adults' cancers [9].

Although numerous researches have revealed the association between survivin and the prognosis of HNSCC, the results still remains controversial due to the variance in the sample size, study design, and cut-off value. Therefore, it is essential to clarify the diagnostic and prognostic value of survivin in HNSCC based on the findings from the independently small sample size publications. Here, we searched PubMed (Medline), Embase, and Web of Science databases for relevant publications and undertaken a comprehensive meta-analysis to systematically assess the diagnostic and prognostic role of survivin in HNSCC.

\section{Methods}

\section{Search strategy}

We searched for articles published between 2000 and 2020. Electronic searches for relevant retrieve studies were performed throughout databases, including PubMed (Medline), Web of Science and EMBASE databases in accordance with Dickersin et al in September 2020 [10]. The retrieval strategy included: (survivin) and (prognosis OR outcome OR mortality OR survival OR progression OR recurrence) and (head and neck or laryngeal or tonsil or oropharyngeal or oral or oropharynx or nasopharyngeal) and (squamous cell cancer or carcinoma). Furthermore, the reference lists of retrieved articles for additional articles were also manually searched. If several studies reported the same patient populations, we enrolled the most complete one to avoid duplication.

\section{Selection criteria}

This meta-analysis was limited to studies about the association between HNSCC and survivin. The inclusion criteria of the meta-analysis were as follows: (1) all patients should be diagnosed with HNSCC; (2) survivin was evaluated in both samples of the HNSCC and normal controls; (3) studies revealed the association between survivin and survival of HNSCC; (4) sufficient statistical analysis was required, including hazard ratios (HR) and their related 95\% confidence interval ( $95 \% \mathrm{Cls})$ ) for survival outcomes, if not we could calculate them by $p$ values and Kaplan-Meier curves [11] (5) the language of publications was limited to English. The exclusion criteria were: (1) studies without sufficient data for meta-analysis; (2) abstracts, case reports, reviews, letters, expert opinions, etc.; (3) studies about cell lines, in vivo/vitro studies, and human xenografts. If the same cohort was reported by several studies, the most recent one was included in our study.

\section{Data extraction}


We inspected the duplicates, and removed the repeated papers first. Then, we perused the titles and abstracts of the papers carefully. At last full articles were selected to include the appropriate studies. Two researchers independently evaluated the literature against the inclusion and exclusion criteria (LQ Zhou and $\mathrm{Y} \mathrm{Hu}$ ). Any discrepancy in assessments was resolved by consulting an adjudicating with a third researcher (HJ Xiao). The researchers of the studies were contacted by e-mail to request data or additional information for meta-analytic calculations. The eligible studies for this meta-analysis were reviewed by two reviewers (LQ Zhou and Y Hu) independently. The Newcastle-Ottawa Quality Assessment Scale was included to assess the methodological qualities of each publication, a star system (maximum is nine stars) was adopted to evaluate a including publications in three domains, comparability of study groups, selection of participants and the outcome measurement. A study with NOS $\geq 6$ was seemed as a high-quality study [12, 13]. Reporting recommendations for tumor marker prognostic studies (REMARK) was also applied to evaluate study quality in cancer-related meta -analysis [14].

\section{Statistical analysis}

The HRs and the related $95 \%$ Cls of survival outcomes were obtained directly from the primary publications or estimated by $p$ values and other published data following Parmer's methods [15]. Statistical heterogeneity among the studies was evaluated using the $\chi^{2}$-based Q test and the $\mathrm{I}^{2}$ statistics [16]. The fixed-effects model was employed for analysis without obvious statistical heterogeneity between studies $\left(P>0.10, I^{2}<50 \%\right)$. Otherwise, the random-effects model was applied. Moreover, we performed subgroup analysis to explore the potential source of heterogeneity. Sensitivity analysis was conducted to investigate the influence of each individual study on the overall pooled results. We used the Begg's and Egger's tests to assess the potential publication bias. We conducted all statistical analyses by STATA statistical software version 15.0 (StataCorp LP).

\section{Results}

Selection and characteristics of included studies. A total of 778 potential records were initially identified by searching the electronic databases (Figure. 1). Following exclusion of the duplicates $(n=353)$, reviews, abstracts and letters $(n=25)$ and the studies of irrelevant topics $(n=296), 77$ studies were remained for further assessment by reading their full-text articles. A total of 49 studies did not provide specific data regarding HNSCC or survivin and therefore were excluded. Finally, a total 4891 HNSCC patients in 28 studies with publication years ranging from 2002 to 2019 were enrolled in the present meta-analysis.

The characteristics of the eligible studies were summarized in Table 1. The participants were from China, Tunisia, Turkey, Germany, Italy, Australia, Canada, South Korea, Sweden and Slovenia. Our meta-analysis including eight studies for laryngeal squamous cell carcinoma (LSCC), ten studies for oral squamous cell carcinomas (OSCC), five studies for head and neck squamous cell carcinoma (HNSCC) and five studies for nasopharyngeal carcinoma (NPC). 15 publications included $>100$ patients and 13 publications enrolled $<100$ patients. 21 studies including a total of 3036 patients reported overall survival (OS). 9 studies including a total of 925 patients reported disease-free survival (DFS) and 3 studies including a total of 1485 patients reported disease-specific survival (DSS). The HR and 95\% Cl were directly reported in 15 studies and were estimated in 13 studies in the original literature. All of the publications' NOS scores were above 6 and the REMARK scores were between 11-15.

Association between survivin and survival outcomes of HNSCC patients. A total of 21 studies in the present analysis examined the association between survivin and the OS of in HNSCC patients. The heterogeneity among the publications in our study was significant for $Q$ test $(P<0.1)$. Hence, the randomeffects model was adopted and subgroup analysis was used to seek for the potential causes of heterogeneity. The results of these studies indicated expression of survivin were associated with poorer OS (HR, 2.02; 95\% Cl, 1.65-2.47, $\mathrm{P}<0.001)$. Medium heterogeneity was noted $\left(\mathrm{I}^{2}=50.3 \%\right.$,

$P_{\text {heterogeneity }}=0.005$ ) (Figure. 2). Nine studies examined the association between survivin and the DFS and 3 studies examined the association between survivin and the DSS in HNSCC patients. Figure 3 summarized HR for DFS (HR $=2.03,95 \% \mathrm{Cl}: 1.64-2.52)$ and DSS $(\mathrm{HR}=1.92,95 \% \mathrm{Cl}$ : $1.41-2.60)$, and there was no significant heterogeneity noted between survivin expression and DFS $\left(I^{2}=0.0 \%, P_{\text {heterogeneity }}=0.875\right)$, low heterogeneity was noted between survivin expression and DSS $\left(I^{2}=40.2 \%\right.$, $\left.P_{\text {heterogeneity }}=0.188\right)$.

Subgroup analysis for OS was also performed and was stratified according to different cancer types. The summarized HR for LSCC was 1.35 (95\% Cl, 1.05$1.74, \mathrm{P}<0.001)$ with low heterogeneity $\left(\mathrm{I}^{2}=42.3 \%\right.$, $\left.\mathrm{P}_{\text {heterogeneity }}=0.158\right)$; for HNSCC was $1.52(95 \% \mathrm{Cl}, 1.25-1.86, \mathrm{P}<0.001)$ with medium heterogeneity $\left(\mathrm{I}^{2}=\right.$ $\left.55.3 \%, \mathrm{P}_{\text {heterogeneity }}=0.062\right)$; for NPC was $2.53(95 \% \mathrm{Cl}, 1.76-3.62, \mathrm{P}<0.001)$ with no significant heterogeneity $\left(\mathrm{I}^{2}=0.0 \%, \mathrm{P}_{\text {heterogeneity }}=0.540\right)$ and for $0 \mathrm{SCC}$ was $2.45(95 \% \mathrm{Cl}, 1.89-3.17, \mathrm{P}<0.001)$ with no significant heterogeneity $\left(\mathrm{I}^{2}=7.7 \%, \mathrm{P}_{\text {heterogeneity }}=0.370\right)(\mathrm{Fig} .4)$.

Sensitivity analysis. The sensitivity analysis was applied to detect the effects of each single study on the overall effect. The analysis did not detect a study that could alter significantly the combined results (Figure. 5). The results of the sensitivity analysis indicated that the pooled effect size of the meta-analysis results was stable and reliable.

Publication bias. The publication bias was assessed by the Begg's funnel plots and the Egger's test in the present study. The results indicated the publication bias existed among the studies ( $p=0.018)$. Therefore, "trim and fill" analysis was further utilized, and the pooled $\mathrm{HR}$ of 1.569 (95\%Cl: $1.276-1.930)$ remained statistically significant (Figure. 6), therefore, the results of the present studies were robust in spite of the significant publication bias.

\section{Discussion}

Numerous studies have focused on the identification of new prognostic biomarkers that can be used for cancer monitoring and detection. An association between survivin expression and survival outcomes has been shown in HNSCC patients. The study by Fiedler et al found that high survivin expression was significantly correlated to unfavorable DSS[19]. Kim et al demonstrated that survivin overexpression had a significant negative effect on survival outcomes of OSCC patients[43]. However, contradictory results were reported by Hansson et al that patients with strong nuclear survivin expression had better 5-year DFS compared with those with weak nuclear survivin expression[35]. The present study is the first meta-analysis including 28 published studies with 4891 
patients to provide useful information for clinical decision-making in HNSCC. Survivin was significantly associated with poorer OS in HNSCC patients, with HR values of 2.02, similar results were found in subgroup analysis stratified by cancer type, such as LSCC, OSCC, NPC, etc. Furthermore, significant correlation between survivin and shorter DFS/ DSS (HR 2.03/ HR 2.92, respectively) was observed. These findings confirmed that survivin could be widely applied as diagnostic markers and therapeutic targets in HNSCC patients.

The prognostic value of survivin was investigated in HNSCC and gathering evidences suggested that survivin was an independent prognostic marker in HNSCC [44, 45]. Epigenetic modifications play roles in HNSCC by regulating survivin expression [46]. The hypomethylation of BIRC5 is an important step in OSCC tumorigenesis due to its GC-rich region [47]. p53 also participates in the survivin upregulation in OSCCs, positive correlation was found between survivin expression and p53 in both HNSCC and premalignant lesions by Khan et al [48]. The survivin gene locus encodes for multiple alternative splice variants with several different functions and heterodimerization possibilities [49]. Twenty HNSCC cell lines at different differentiation levels showed higher survivin expressed levels compared to a human cell line of neonatal keratinocyte [50]. Targeted therapies have produced striking benefits for patients with cancers. Survivin is preferable targets of therapeutic modalities, namely antisense nucleotides, small-molecule inhibitors, antitumor immunotherapy and RNA interference [51, 52]. According to our results, the survivin inhibitors could be the therapeutics against the HNSCC.

However, the present meta-analysis also had several limitations. First, we found that different paper qualities and sample sizes across the studies might cause bias in the meta-analysis. Second, the cut-off value defining positive survivin expression varied among eligible studies (Table 1). Third, our analysis might overestimate the prognostic significance of survivin to some degree due to the positive results reported in most of the including publications. Forth, partial survival data of some including papers were extracted from Kaplan-Meier curves and may not as accurate as that obtained from original paper directly.

In conclusion, we searched the electronic databases and a total of 4891 patients in 28 studies were enrolled for meta-analysis, the results demonstrating that patients with survivin expression are more likely to have worse prognosis. Taken together, our meta-analysis results suggest that survivin gains a prognostic and diagnostic value for the HNSCC patients. However, more larger sample size studies are required to acquire a more representative and precise result.

\section{Declarations}

Ethics approval and consent to participate: Not applicable.

Consent for publication: I understand that the text and any pictures or videos published in the article will be freely available on the internet and may be seen by the general public. The pictures, videos and text may also appear on other websites or in print, may be translated into other languages or used for commercial purposes.

Availability of data and materials: All data generated or analysed during this study are included in this published article [and its supplementary information files].

Competing interests:The author(s) declare(s) that they have no competing interests.

Funding: Not applicable.

Authors' contributions:YH and LZ collected and analyzed the data, wrote the paper. LZ, YH and HX analyzed the data and wrote the paper. LZ and HX conceived and designed this study, analyzed the data, wrote the paper. All authors read and approved the final manuscript.

Acknowledgements: Not applicable.

Data availability statements

All data generated or analysed during this study are included in this published article [and its supplementary information files].

The data that support the findings of this study are available from the corresponding author upon reasonable request.

\section{References}

1. Jemal A, Siegel R, Xu J, Ward E: Cancer statistics, 2010. CA Cancer J Clin 2010, 60(5):277-300.

2. Leemans CR, Braakhuis BJ, Brakenhoff RH: The molecular biology of head and neck cancer. Nat Rev Cancer 2011, 11(1):9-22.

3. Castellsagué X, Quintana MJ, Martínez MC, Nieto A, Sánchez MJ, Juan A, Monner A, Carrera M, Agudo A, Quer M et al: The role of type of tobacco and type of alcoholic beverage in oral carcinogenesis. Int J Cancer 2004, 108(5):741-749.

4. Brockstein B, Haraf DJ, Rademaker AW, Kies MS, Stenson KM, Rosen F, Mittal BB, Pelzer H, Fung BB, Witt ME et al: Patterns of failure, prognostic factors and survival in locoregionally advanced head and neck cancer treated with concomitant chemoradiotherapy: a 9-year, 337-patient, multi-institutional experience. Ann Oncol 2004, 15(8):1179-1186.

5. Ambrosini G, Adida C, Altieri DC: A novel anti-apoptosis gene, survivin, expressed in cancer and lymphoma. Nat Med 1997, 3(8):917-921.

6. Altieri DC: Survivin, versatile modulation of cell division and apoptosis in cancer. Oncogene 2003, 22(53):8581-8589. 
7. Coumar MS, Tsai FY, Kanwar JR, Sarvagalla S, Cheung CH: Treat cancers by targeting survivin: just a dream or future reality? Cancer Treat Rev 2013, 39(7):802-811.

8. Niu TK, Cheng Y, Ren X, Yang JM: Interaction of Beclin 1 with survivin regulates sensitivity of human glioma cells to TRAIL-induced apoptosis. FEBS Lett 2010, 584(16):3519-3524.

9. O'Connor DS, Schechner JS, Adida C, Mesri M, Rothermel AL, Li F, Nath AK, Pober JS, Altieri DC: Control of apoptosis during angiogenesis by survivin expression in endothelial cells. Am J Pathol 2000, 156(2):393-398.

10. Dickersin K, Scherer R, Lefebvre C: Identifying relevant studies for systematic reviews. Bmj 1994, 309(6964):1286-1291.

11. Parmar MK, Torri V, Stewart L: Extracting summary statistics to perform meta-analyses of the published literature for survival endpoints. Stat Med 1998, 17(24):2815-2834.

12. Wells GA, Shea B, O'Connell D, Peterson J, Welch V, Losos M, Tugwell P: The Newcastle-Ottawa Scale (NOS) for assessing the quality of nonrandomised studies in meta-analyses. In.: Oxford; 2000.

13. Stang A: Critical evaluation of the Newcastle-Ottawa scale for the assessment of the quality of nonrandomized studies in meta-analyses. Eur $J$ Epidemiol 2010, 25(9):603-605.

14. Sauerbrei W, Taube SE, McShane LM, Cavenagh MM, Altman DG: Reporting Recommendations for Tumor Marker Prognostic Studies (REMARK): An Abridged Explanation and Elaboration. J Natl Cancer Inst 2018, 110(8):803-811.

15. Extracting summary statistics to perform meta-analysis of the published literature for survival endpoints by M. Parmar, V. Torri and L. Stewart, Statistics in Medicine 1998; 17: 2815 -2834 (p 1817). Statistics in Medicine 2010, 23(11):1817-1817.

16. Higgins JP, Thompson SG, Deeks JJ, Altman DG: Measuring inconsistency in meta-analyses. BMJ (Clinical research ed) 2003, 327(7414):557-560.

17. Ben Elhadj M, Amine OEL, Mokni Baizig N, Ben Ayoub W, Goucha A, El May MV, Fourati A: Expression Profile of Survivin and p16 in Laryngeal Squamous Cell Carcinoma: Contribution of Tunisian Patients. Ear Nose Throat J 2019:145561319855644.

18. Erpolat OP, Gocun PU, Akmansu M, Karakus E, Akyol G: High expression of nuclear survivin and Aurora B predicts poor overall survival in patients with head and neck squamous cell cancer. Strahlenther Onkol 2012, 188(3):248-254.

19. Fiedler M, Weber F, Hautmann MG, Haubner F, Reichert TE, Klingelhöffer C, Schreml S, Meier JK, Hartmann A, Ettl T: Biological predictors of radiosensitivity in head and neck squamous cell carcinoma. Clin Oral Investig 2018, 22(1):189-200.

20. Jin PY, Zheng ZH, Lu HJ, Yan J, Zheng GH, Zheng YL, Wu DM, Lu J: Roles of $\beta$-catenin, TCF-4, and survivin in nasopharyngeal carcinoma: correlation with clinicopathological features and prognostic significance. Cancer Cell Int 2019, 19:48.

21. Li YH, Hu CF, Shao Q, Huang MY, Hou JH, Xie D, Zeng YX, Shao JY: Elevated expressions of survivin and VEGF protein are strong independent predictors of survival in advanced nasopharyngeal carcinoma. J Transl Med 2008, 6:1.

22. Li DW, Gao S, Shen B, Dong P: Effect of apoptotic and proliferative indices, P-glycoprotein and survivin expression on prognosis in laryngeal squamous cell carcinoma. Med Oncol 2011, 28 Suppl 1:S333-340.

23. Lin $\mathrm{CY}$, Hung HC, Kuo RC, Chiang CP, Kuo MY: Survivin expression predicts poorer prognosis in patients with areca quid chewing-related oral squamous cell carcinoma in Taiwan. Oral Oncol 2005, 41(6):645-654.

24. Lo Muzio L, Farina A, Rubini C, Pezzetti F, Stabellini G, Laino G, Santarelli A, Pannone G, Bufo P, de Lillo A et al: Survivin as prognostic factor in squamous cell carcinoma of the oral cavity. Cancer Lett 2005, 225(1):27-33.

25. Preuss SF, Weinell A, Molitor M, Stenner M, Semrau R, Drebber U, Weissenborn SJ, Speel EJ, Wittekindt C, Guntinas-Lichius 0 et al: Nuclear survivin expression is associated with HPV-independent carcinogenesis and is an indicator of poor prognosis in oropharyngeal cancer. Br J Cancer 2008 , 98(3):627-632.

26. Tastekin E, Caloglu VY, Durankus NK, Sut N, Turkkan G, Can N, Puyan FO, Caloglu M: Survivin expression, HPV positivity and microvessel density in oropharyngeal carcinomas and relationship with survival time. Arch Med Sci 2017, 13(6):1467-1473.

27. Wang HY, Sun BY, Zhu ZH, Chang ET, To KF, Hwang JS, Jiang H, Kam MK, Chen G, Cheah SL et al: Eight-signature classifier for prediction of nasopharyngeal [corrected] carcinoma survival. J Clin Oncol 2011, 29(34):4516-4525.

28. Xiang Y, Yao H, Wang S, Hong M, He J, Cao S, Min H, Song E, Guo X: Prognostic value of Survivin and Livin in nasopharyngeal carcinoma. Laryngoscope 2006, 116(1):126-130.

29. Yip KW, Shi W, Pintilie M, Martin JD, Mocanu JD, Wong D, MacMillan C, Gullane P, O'Sullivan B, Bastianutto C et al: Prognostic significance of the Epstein-Barr virus, p53, Bcl-2, and survivin in nasopharyngeal cancer. Clin Cancer Res 2006, 12(19):5726-5732.

30. Kim MJ, Lim KY, Kim JW, Nam IW, Lee JH, Myoung H: Stage and mRNA expression of survivin in lymph node as prognostic indicators in patients with oral squamous cell carcinoma. Cancer Lett 2005, 224(2):253-261.

31. Dong Y, Sui L, Watanabe Y, Sugimoto K, Tokuda M: Survivin expression in laryngeal squamous cell carcinomas and its prognostic implications. Anticancer Res 2002, 22(4):2377-2383.

32. Zhang M, Li J, Wang L, Tian Z, Zhang P, Xu Q, Zhang C, Wei F, Chen W: Prognostic significance of p21, p27 and survivin protein expression in patients with oral squamous cell carcinoma. Oncol Lett 2013, 6(2):381-386.

33. Farnebo L, Tiefenböck K, Ansell A, Thunell LK, Garvin S, Roberg K: Strong expression of survivin is associated with positive response to radiotherapy and improved overall survival in head and neck squamous cell carcinoma patients. Int J Cancer 2013, 133(8):1994-2003.

34. Freier K, Pungs S, Sticht C, Flechtenmacher C, Lichter P, Joos S, Hofele C: High survivin expression is associated with favorable outcome in advanced primary oral squamous cell carcinoma after radiation therapy. Int J Cancer 2007, 120(4):942-946.

Page 5/12 
35. Tiefenböck-Hansson K, Haapaniemi A, Farnebo L, Palmgren B, Tarkkanen J, Farnebo M, Munck-Wikland E, Mäkitie A, Garvin S, Roberg K: WRAP53 $\beta$, survivin and p16INK4a expression as potential predictors of radiotherapy/chemoradiotherapy response in T2N0-T3N0 glottic laryngeal cancer. Oncol Rep 2017, 38(4):2062-2068.

36. Münscher A, Prochnow S, Gulati A, Sauter G, Lörincz B, Blessmann M, Hanken H, Böttcher A, Clauditz TS: Survivin expression in head and neck squamous cell carcinomas is frequent and correlates with clinical parameters and treatment outcomes. Clin Oral Investig 2019, 23(1):361-367.

37. Pickhard A, Gröber S, Haug AK, Piontek G, Wirth M, Straßen U, Rudelius M, Reiter R: Survivin and pAkt as potential prognostic markers in squamous cell carcinoma of the head and neck. Oral Surg Oral Med Oral Pathol Oral Radiol 2014, 117(6):733-742.

38. Su L, Wang Y, Xiao M, Lin Y, Yu L: Up-regulation of survivin in oral squamous cell carcinoma correlates with poor prognosis and chemoresistance. Oral Surg Oral Med Oral Pathol Oral Radiol Endod 2010, 110(4):484-491.

39. Troiano G, Guida A, Aquino G, Botti G, Losito NS, Papagerakis S, Pedicillo MC, lonna F, Longo F, Cantile M et al: Integrative Histologic and Bioinformatics Analysis of BIRC5/Survivin Expression in Oral Squamous Cell Carcinoma. Int J Mol Sci 2018, 19(9).

40. Pizem J, Cör A, Gale N: Survivin expression is a negative prognostic marker in laryngeal squamous cell carcinoma and is associated with p53 accumulation. Histopathology 2004, 45(2):180-186.

41. Marioni G, Staffieri A, Lionello M, Tealdo G, Staffieri C, Giacomelli L, Friso ML, Stramare R, Ottaviano G, Blandamura S: Relationship between antiapoptotic proteins survivin and $\mathrm{Bcl}-2$, and response to treatment in patients undergoing post-operative RT for laryngeal cancer: a pilot study. $J$ Oral Pathol Med 2013, 42(4):339-344.

42. Marioni G, Ottaviano G, Marchese-Ragona R, Fasanaro E, Tealdo G, Zanotti C, Randon B, Giacomelli L, Stellini E, Blandamura S: Nuclear survivin expression correlates with endoglin-assessed microvascularisation in laryngeal carcinoma. J Clin Pathol 2017, 70(12):1033-1037.

43. Kim YH, Kim SM, Kim YK, Hong SP, Kim MJ, Myoung H: Evaluation of survivin as a prognostic marker in oral squamous cell carcinoma. J Oral Pathol Med 2010, 39(5):368-375.

44. Riedl J, Posch F, Konigsbrugge O, Lotsch F, Reitter EM, Eigenbauer E, Marosi C, Schwarzinger I, Zielinski C, Pabinger I et al: Red cell distribution width and other red blood cell parameters in patients with cancer: association with risk of venous thromboembolism and mortality. PloS one 2014, 9(10):e111440.

45. Yilmaz A, Malya F, Ozturk G, Citgez B, Ozdenkaya Y, Ersavas C, Agan A, Senturk H, Karatepe O: Effect of pre-operative red blood cell distribution on cancer stage and morbidity rate in patients with pancreatic cancer. International journal of clinical and experimental medicine 2014, 7(9):3072-3075.

46. Lyu H, Huang J, He Z, Liu B: Epigenetic mechanism of survivin dysregulation in human cancer. Sci China Life Sci 2018, 61(7):808-814.

47. Chen YK, Hsue SS, Lin LM: Survivin expression is regulated by an epigenetic mechanism for DMBA-induced hamster buccal-pouch squamous-cell carcinomas. Arch Oral Biol 2005, 50(6):593-598.

48. Khan Z, Tiwari RP, Mulherkar R, Sah NK, Prasad GB, Shrivastava BR, Bisen PS: Detection of survivin and p53 in human oral cancer: correlation with clinicopathologic findings. Head Neck 2009, 31(8):1039-1048.

49. De Maria S, Pannone G, Bufo P, Santoro A, Serpico R, Metafora S, Rubini C, Pasquali D, Papagerakis SM, Staibano S et al: Survivin geneexpression and splicing isoforms in oral squamous cell carcinoma. J Cancer Res Clin Oncol 2009, 135(1):107-116.

50. Michi Y, Morita I, Amagasa T, Murota S: Human oral squamous cell carcinoma cell lines promote angiogenesis via expression of vascular endothelial growth factor and upregulation of KDR/flk-1 expression in endothelial cells. Oral Oncol 2000, 36(1):81-88.

51. Cheng SM, Chang YC, Liu CY, Lee JY, Chan HH, Kuo CW, Lin KY, Tsai SL, Chen SH, Li CF et al: YM155 down-regulates survivin and XIAP, modulates autophagy and induces autophagy-dependent DNA damage in breast cancer cells. Br J Pharmacol 2015, 172(1):214-234.

52. Santarelli A, Mascitti M, Lo Russo L, Sartini D, Troiano G, Emanuelli M, Lo Muzio L: Survivin-Based Treatment Strategies for Squamous Cell Carcinoma. Int J Mol Sci 2018, 19(4).

\section{Table}

Table 1. Characteristics of the studies examined in the meta-analysis. 


\begin{tabular}{|c|c|c|c|c|c|c|c|c|c|c|c|}
\hline Author & Year & Country & $\begin{array}{l}\text { Cancer } \\
\text { type }\end{array}$ & $\begin{array}{l}\text { Sample } \\
\text { size }\end{array}$ & Age & $\begin{array}{l}\text { Follow-up } \\
\text { [month } \square\end{array}$ & $\begin{array}{l}\text { Survival } \\
\text { analysis }\end{array}$ & Method & $\begin{array}{l}\text { Cut-off } \\
\text { value }\end{array}$ & HR & $\begin{array}{l}\text { NOS/REMARK } \\
\text { score }\end{array}$ \\
\hline Elhadj[17] & 2019 & Tunisia & LSCC & 70 & $63(45-88)$ & NR & OS, DFS & IHC & $5 \%$ & Reported & $7 / 12$ \\
\hline Erpolat[18] & 2012 & Turkey & HNSCC & 58 & $\begin{array}{l}56.7(35- \\
80)\end{array}$ & $\begin{array}{l}56.5(38.7- \\
112.5)\end{array}$ & OS & IHC & $5 \%$ & Reported & $7 / 11$ \\
\hline Fiedler[19] & 2017 & Germany & HNSCC & 139 & $\begin{array}{l}60.5(43.4- \\
83.6)\end{array}$ & $\begin{array}{l}17.4(0- \\
120.9)\end{array}$ & OS,DSS & IHC & $\begin{array}{l}\text { median } \\
\text { value }\end{array}$ & Reported & $6 / 14$ \\
\hline Jin[20] & 2019 & China & NPC & 164 & $\begin{array}{l}45.0(24- \\
70)\end{array}$ & $\begin{array}{l}49.2(9- \\
60)\end{array}$ & $\begin{array}{l}\text { OS,DMFS, } \\
\text { LRFS,DFS }\end{array}$ & $\begin{array}{l}\text { IHC,RT- } \\
\text { qPCR }\end{array}$ & $0 \%$ & Reported & $6 / 13$ \\
\hline $\operatorname{Li}[21]$ & 2008 & China & NPC & 280 & $46(14-86 \square$ & NR & OS & IHC & $5 \%$ & Reported & $7 / 11$ \\
\hline $\mathrm{Li}[22]$ & 2011 & China & LSCC & 86 & $51(37-84)$ & NR & OS & IHC & $0 \%$ & Reported & $7 / 12$ \\
\hline Lin[23] & 2005 & China & OSCC & 96 & NR & NR & OS & IHC & $25 \%$ & Reported & $6 / 12$ \\
\hline Muzio [24] & 2005 & Italy & OSCC & 78 & $\begin{array}{l}66.5(18- \\
87)\end{array}$ & 72 & DSS & IHC & $75 \%$ & Reported & $7 / 12$ \\
\hline Preuss[25] & 2008 & Australia & OSCC & 106 & $57(34-82)$ & $\begin{array}{l}20.3(0.33- \\
79.8)\end{array}$ & DFS & IHC & $5 \%$ & Reported & $7 / 13$ \\
\hline Tastekin[26] & 2017 & Turkey & OSCC & 46 & $\begin{array}{l}59.48(31- \\
91)\end{array}$ & NR & OS & IHC & $13.00 \%$ & Reported & $6 / 11$ \\
\hline Wang[27] & 2011 & China & NPC & 1268 & $46 \square 15-90 \square$ & 69ロ1-20ם & DSS & IHC & $\begin{array}{l}\text { median } \\
\text { value }\end{array}$ & Reported & $7 / 13$ \\
\hline Xiang[28] & 2006 & China & NPC & 80 & NR & 60 & OS, DFS & IHC & $25 \%$ & Reported & $7 / 13$ \\
\hline Yip[29] & 2006 & Canada & NPC & 198 & NR & 136.8 & OS & IHC & $5 \%$ & Reported & $8 / 15$ \\
\hline Zhao[29] & 2008 & China & LSCC & 146 & $\begin{array}{l}54.6(42- \\
76)\end{array}$ & $\begin{array}{l}41.4(36- \\
72)\end{array}$ & $\overline{D F S}$ & IHC & $5 \%$ & Reported & $7 / 14$ \\
\hline Kim[30] & 2002 & China & LSCC & 102 & $\begin{array}{l}63.49 \square 38- \\
89 \square\end{array}$ & NR & OS,DFS & IHC & $5 \%$ & Reported & $7 / 13$ \\
\hline Dong [31] & 2005 & $\begin{array}{l}\text { South } \\
\text { Korea }\end{array}$ & OSCC & 113 & $58(18-78)$ & NR & OS & IHC & $50 \%$ & Estimated & $6 / 12$ \\
\hline Zhang[32] & 2013 & China & OSCC & 110 & $58(37-78)$ & $>60$ & OS & IHC & $\begin{array}{l}\text { median } \\
\text { value }\end{array}$ & Estimated & $7 / 13$ \\
\hline Farnebo[33] & 2013 & Sweden & HNSCC & 40 & 68 & 30 & OS & IHC & $0 \%$ & Estimated & $6 / 11$ \\
\hline Freier[34] & 2007 & Germany & OSCC & 296 & 60ロ16-92ם & $34 \llbracket 0-147 \square$ & OS & IHC & $10 \%$ & Estimated & $7 / 13$ \\
\hline Hansson[35] & 2017 & Sweden & LSCC & 149 & NR & 67ロ9-163ロ & DFS & IHC & $10 \%$ & Estimated & $7 / 11$ \\
\hline Munscher[36] & 2019 & Germany & HNSCC & 452 & NR & $\begin{array}{l}41.3 \square 1- \\
306 \square\end{array}$ & OS,RFS & IHC & $50 \%$ & Estimated & $7 / 11$ \\
\hline Pickhard[37] & 2014 & Germany & HNSCC & 180 & $53 \square 35-72 \square$ & $60-162$ & OS & IHC & $10 \%$ & Estimated & $6 / 11$ \\
\hline Su[38] & 2010 & China & OSCC & 78 & NR & NR & OS & IHC,RT-PCR & $\begin{array}{l}\text { median } \\
\text { value }\end{array}$ & Estimated & $6 / 11$ \\
\hline Troiano [39] & 2018 & Italy & OSCC & 342 & NR & NR & OS & IHC & $60 \%$ & Estimated & $7 / 11$ \\
\hline Pizem[40] & 2004 & Slovenia & LSCC & 68 & $\begin{array}{l}59.2(37- \\
78)\end{array}$ & NR & OS & IHC & $50 \%$ & Estimated & $6 / 12$ \\
\hline Marioni[41] & 2013 & Italy & LSCC & 33 & NR & 43 & DFS & IHC & $10.00 \%$ & Estimated & $6 / 11$ \\
\hline Marioni[42] & 2017 & Italy & LSCC & 75 & 63.6 & 67.3 & DFS & IHC & $6 \%$ & Estimated & $7 / 13$ \\
\hline Kim[43] & 2010 & $\begin{array}{l}\text { South } \\
\text { Korea }\end{array}$ & OSCC & 38 & $\begin{array}{l}58.5(40- \\
75)\end{array}$ & NR & OS & IHC & $20 \%$ & Estimated & $6 / 11$ \\
\hline
\end{tabular}

\section{Figures}




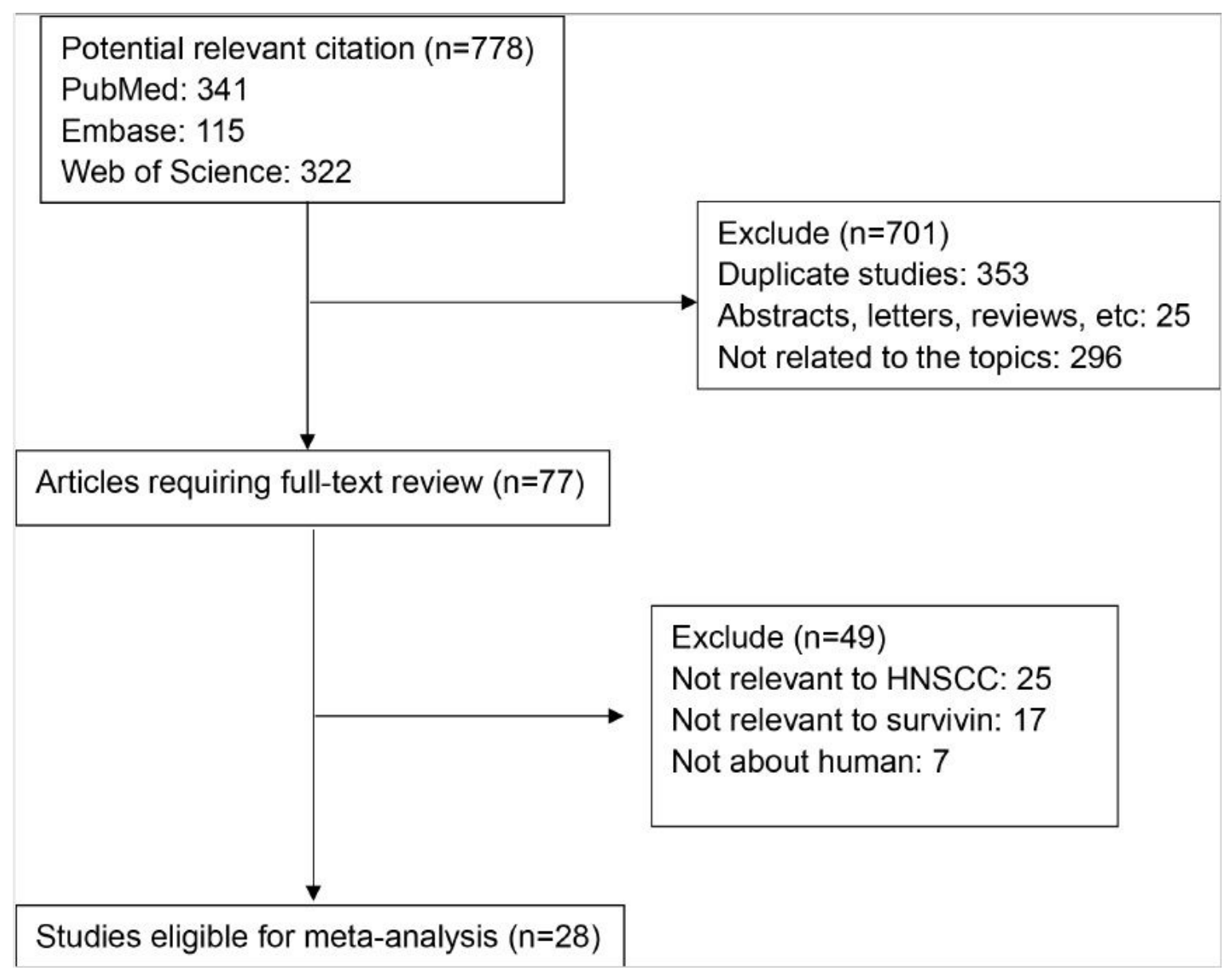

Figure 1

Flow diagram of the selection of relevant studies included in the meta-analysis. 
Study

ID

$\mathrm{HR}(95 \% \mathrm{Cl}) \quad$ Weight

\begin{tabular}{|c|c|c|c|}
\hline Elhadj (2019) & & $1.76(0.56,5.58)$ & 2.42 \\
\hline Erpolat (2012) & & $0.37(0.08,1.66)$ & 1.57 \\
\hline Fiedler (2017) & & $2.53(1.19,5.41)$ & 4.36 \\
\hline $\operatorname{Jin}(2019)$ & & $4.48(1.51,13.30)$ & 2.64 \\
\hline Li (2008) & & $2.13(1.30,3.49)$ & 6.72 \\
\hline Li (2011) & & $1.89(1.09,3.28)$ & 6.14 \\
\hline Lin (2005) & & $1.86(1.05,3.31)$ & 5.89 \\
\hline Tastekin (2017) & & $4.92(2.58,9.40)$ & 5.23 \\
\hline Xiang (2006) & & $3.76(1.35,10.42)$ & 2.91 \\
\hline Yip (2006) & & $2.30(1.10,4.90)$ & 4.44 \\
\hline $\operatorname{Kim}(2005)$ & & $2.60(1.28,5.51)$ & 4.56 \\
\hline Zhang (2013) & & $1.30(0.50,3.40)$ & 3.19 \\
\hline Farnebo (2013) & & $2.40(1.24,4.65)$ & 5.11 \\
\hline Freier (2007) & & $2.47(1.02,5.96)$ & 3.58 \\
\hline Munscher (2019) & & $1.37(1.09,1.72)$ & 9.81 \\
\hline Pickhard (2014) & & $2.30(1.11,4.92)$ & 4.45 \\
\hline Dong (2002) & & $1.80(1.11,3.35)$ & 6.11 \\
\hline Su (2010) & & $2.71(1.46,5.10)$ & 5.41 \\
\hline Troiano (2018) & & $2.04(1.01,4.10)$ & 4.78 \\
\hline Pizem (2004) & & $1.02(1.01,2.03)$ & 8.38 \\
\hline $\operatorname{Kim}(2010)$ & & $1.91(0.58,6.27)$ & 2.30 \\
\hline Overall $(1-$ squared $=50.3 \%, p=0.005)$ & & $2.02(1.65,2.47)$ & 100.00 \\
\hline NOTE: Weights are from random effects analysis & & & \\
\hline $\begin{array}{c}1 \\
.0752\end{array}$ & 1 & & \\
\hline
\end{tabular}

Figure 2

Forest plot indicating the association between survivin expression and OS in HNSCC. 
Study

ID

$\%$

ES $(95 \% \mathrm{Cl}) \quad$ Weight

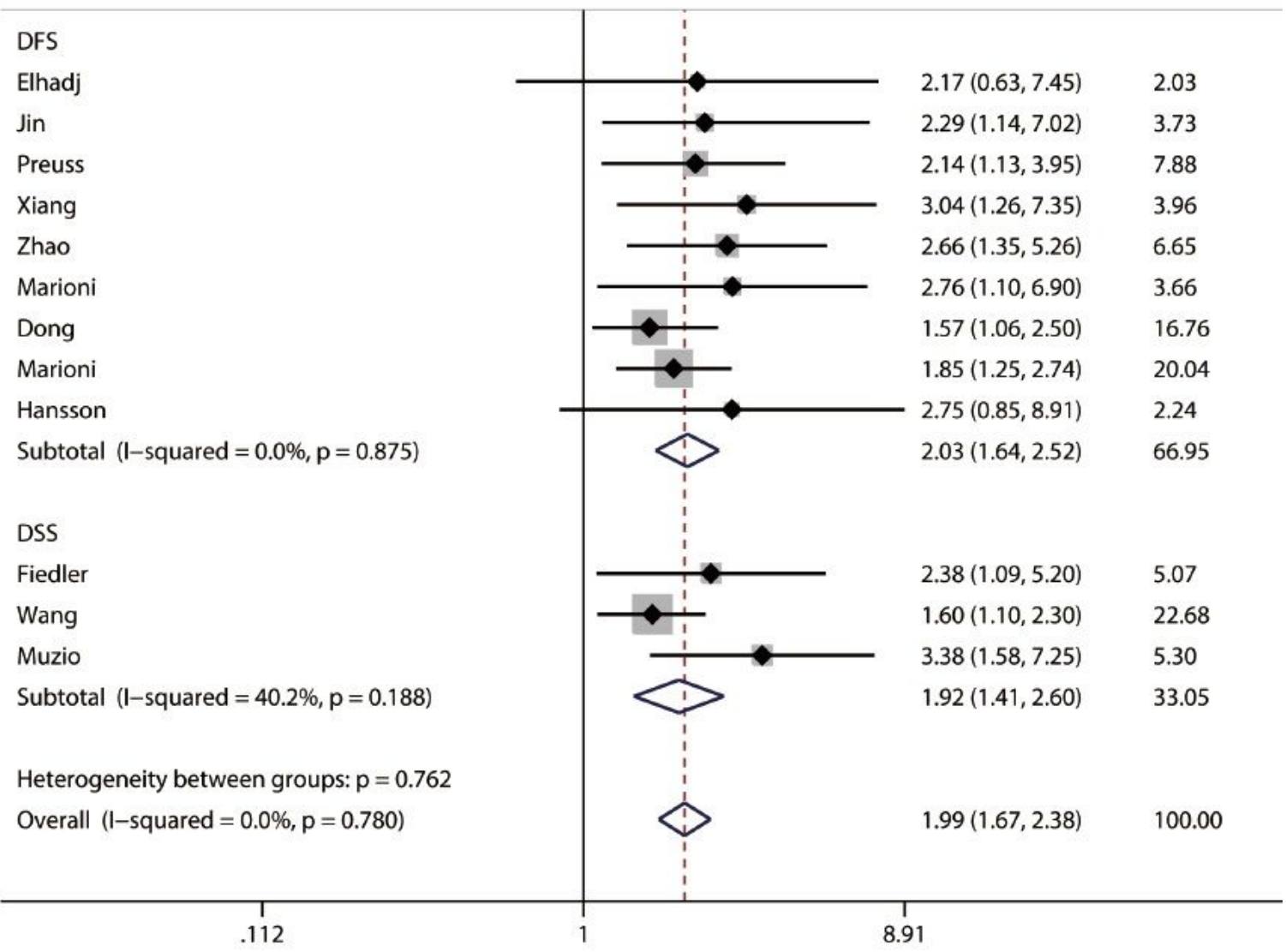

Figure 3

Forest plot examining the association between survivin expression and DFS/DSS in HNSCC. 


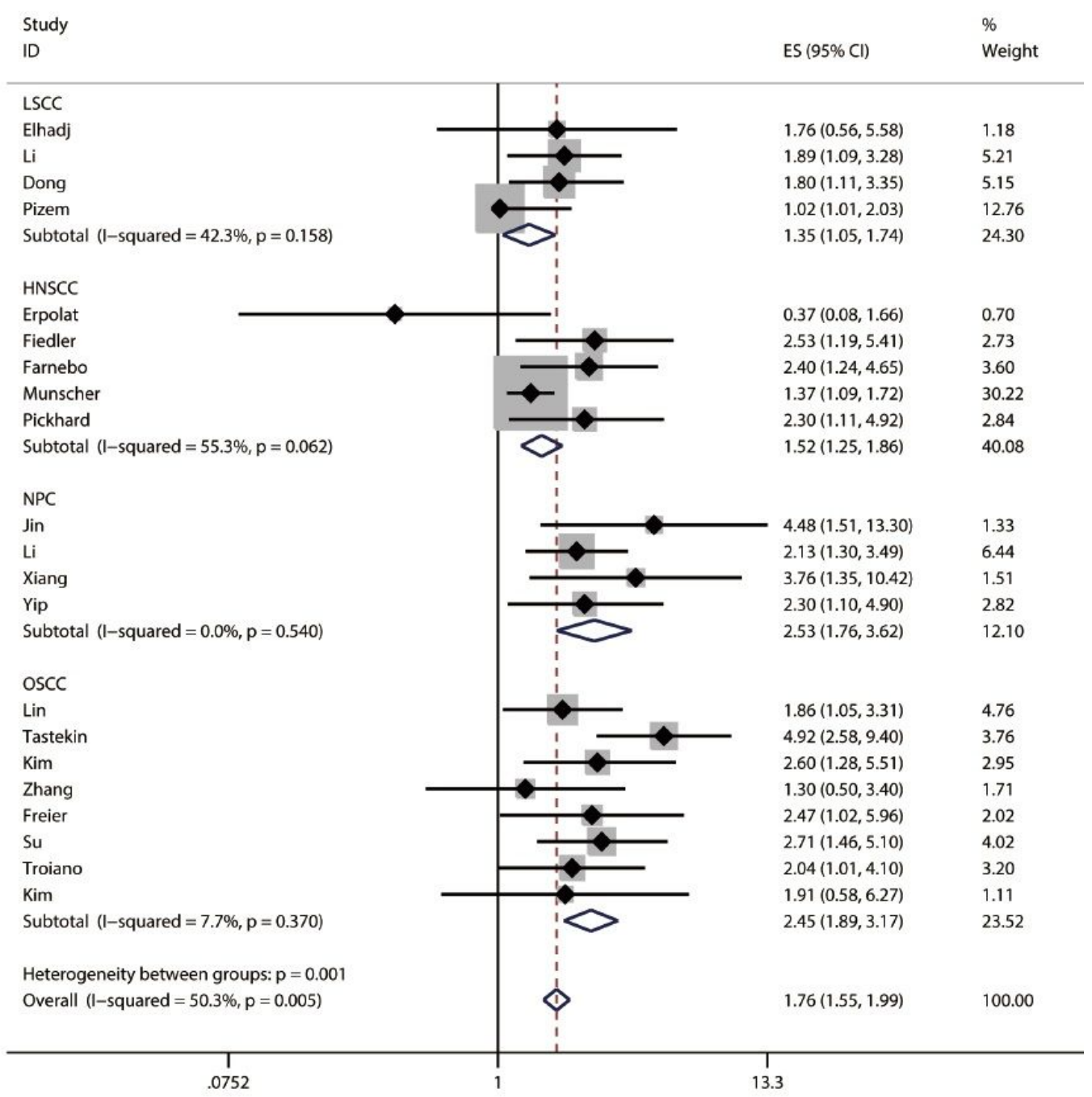

Figure 4

Forest plot of OS in association with survivin in different types of HNSCC.

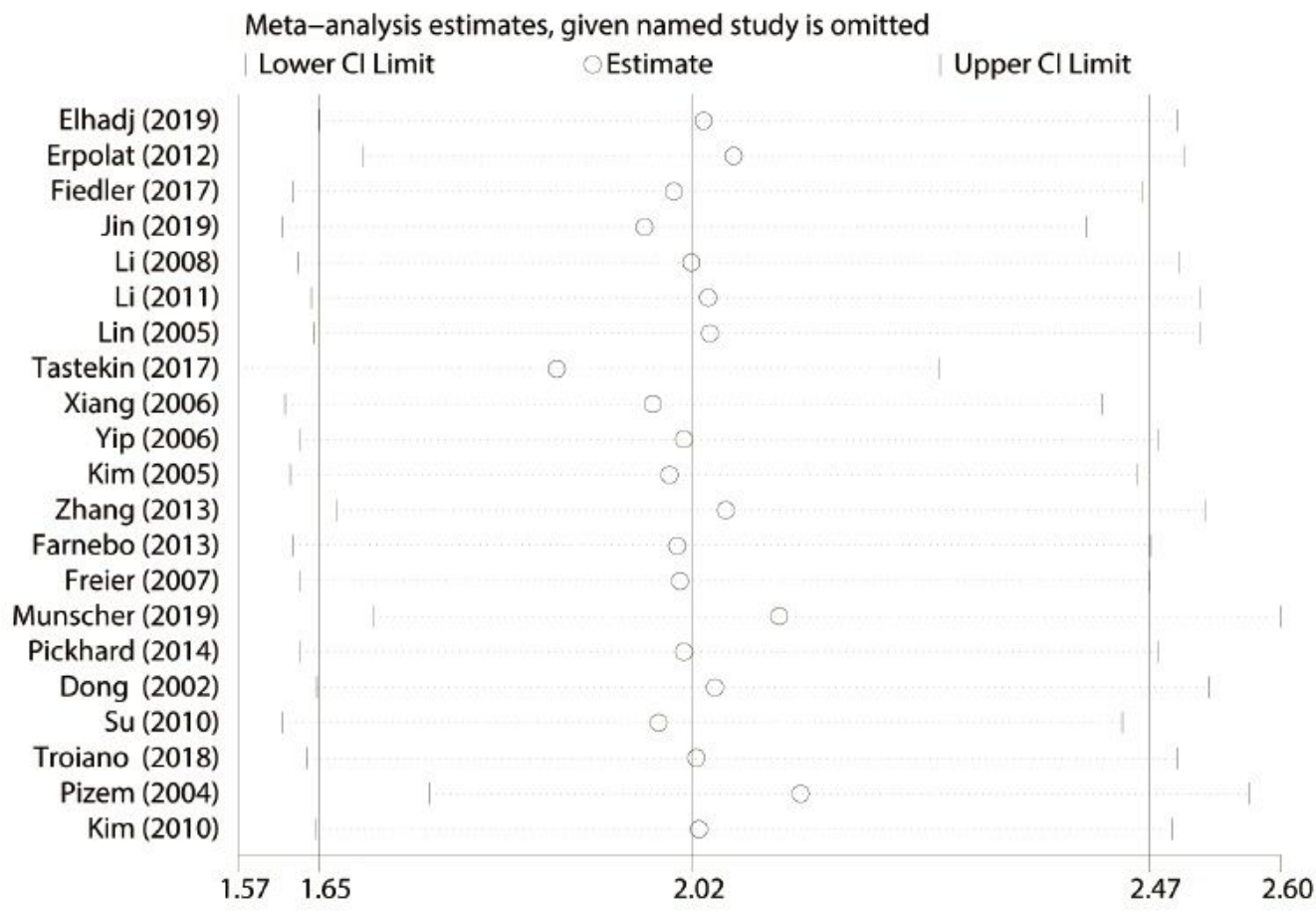


Figure 5

The sensitivity analyses were conducted to evaluate the effects of each single study on the overall effect.
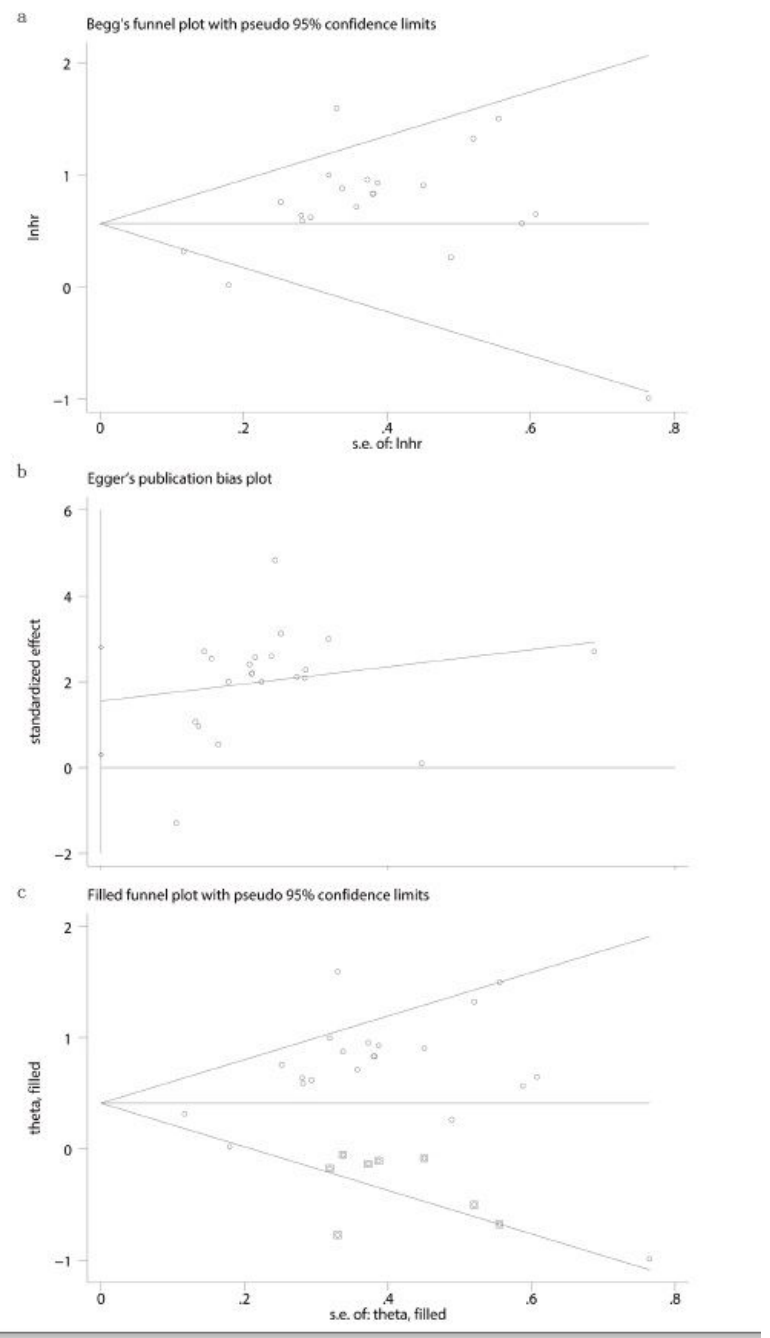

\section{Figure 6}

Publication bias and trim and fill analysis of the enrolled analysis. a. the Begg's funnel plots; b. the Egger's test. c. trim and fill analysis. 